\title{
Counteracting the negative effects of rapeseed and rapeseed press cake in pig diets*
}

\author{
BY FRIEDRICH SCHÖNE ${ }^{1}$, BERND RUDOLPH ${ }^{1}$, ULRICH KIRCHHEIM ${ }^{1}$ \\ AND GÜNTER KNAPP ${ }^{2}$ \\ ${ }^{1}$ Agricultural Institution of Thuringia (Jena), Department of Nutrition and the Market, \\ D-07751 Jena-Remderoda, Germany \\ ${ }^{2}$ Institute of Analytical Chemistry, Micro- and Radiochemistry, Technical University of Graz, \\ A-8010 Graz, Austria
}

(Received 26 April 1996 - Revised 6 May 1997 - Accepted 13 May 1997)

\begin{abstract}
Rapeseed and rapeseed press cake were tested in four long-term experiments with a total of ninetyeight pigs. Rapeseed contained 20 and rapeseed press cake $19 \mathrm{mmol}$ glucosinolates $/ \mathrm{kg} \mathrm{DM}$. The proportion of the tested rapeseed products in feed amounted to 0 (control), 50, 100 and $150 \mathrm{~g} / \mathrm{kg}$ diet. Moist-heat-treated rapeseed and rapeseed press cake with an extremely low glucosinolate content were also given at $150 \mathrm{~g} / \mathrm{kg}$ diet. Each dietary rapeseed product level was given with 125 or $250 \mu \mathrm{g}$ supplementary $\mathbf{I} / \mathrm{kg}$ diet. Reduced feed intake and growth retardation were found in groups receiving $150 \mathrm{~g}$ rapeseed products/ $\mathrm{kg}$ diet; in the case of rapeseed the impairments were significant. Rapeseed products $\geq 100 \mathrm{~g} / \mathrm{kg}$ diet increased the thyroid weight and decreased the serum thyroxine $\left(T_{4}\right)$ concentration. Higher $I$ dosage brought the serum $T_{4}$ concentration to the level of the control group and retarded thyroid enlargement. Intake of rapeseed products lowered the $I$ content of the thyroid; however, there was no significant difference between groups given $0.9 \mathrm{mmol}$ glucosinolates/ kg diet and those receiving three times as much. Degrading glucosinolates by moisture and heat prevented feed intake depression and growth retardation. In the case of treated rapeseed the decreased serum $T_{4}$ concentration and increased thyroid weight persisted, indicating formation of some antithyroid compounds due to myrosinase (EC 3.2.3.1) activation. A maximal glucosinolate content of $2 \mathrm{mmol} / \mathrm{kg}$ diet and additional I application are a prerequisite for using rapeseed products in pig feeding.
\end{abstract}

Rapeseed: Iodine: Thyroid hormones: Pigs

In Germany, rapeseed (Brassica napus var. oleifera) products are the most important home-grown protein feeds, representing $7 \%$ of the 20 million tonnes annual compound feed production. The processed residue of solvent-extracted rapeseed meal from oil mills dominates. Ground rapeseed acts as a temporary energy feed in case of low rapeseed prices and rapeseed press cake, a newer feed processed in smaller screw presses in agricultural plants (Lüdke \& Schöne, 1994) combines advantageous contents of protein $(300-350 \mathrm{~g} / \mathrm{kg})$ and fat $(100-200 \mathrm{~g} / \mathrm{kg})$.

The success of rapeseed feeds is due to the creation of double zero varieties $(<20 \mathrm{~g}$ erucic acid $/ \mathrm{kg},<25 \mathrm{mmol}$ glucosinolates $/ \mathrm{kg}$, based on $910 \mathrm{~g} / \mathrm{kg} \mathrm{DM}$ ). Glucosinolates may impair feed intake, growth and thyroid function in farm animals, particularly in pigs and poultry. A large number of experiments with rapeseed meal or ground rapeseed from high-

* Presented in part at the 48th Annual Meeting of the Gesellschaft für Ernährungsphysiologie, Göttingen, Germany (Schöne et al. 1994a) and at the Ninth International Rapeseed Congress, Cambridge, Cambs. (Schöne et al. 1995). 
glucosinolate cultivars have demonstrated significant feed intake depression, growth retardation, enlargement of thyroid or liver and of the corresponding parenchyma cells respectively, and a decreased serum thyroxine $\left(\mathrm{T}_{4}\right)$ concentration (McKinnon \& Bowland, 1979; Rowan \& Lawrence, 1986; Schöne et al. 1991a,b; Spiegel et al. 1993). In experiments with rapeseed from newly bred low-glucosinolate cultivars the animal response seems to be low (Rundgren, 1983; Bell, 1984; Bourdon \& Aumaitre, 1990; Schöne et al. 1991a). However, a safe level of use for rapeseed products has still to be defined with dose-response experiments (Campbell \& McDonald, 1991).

Glucosinolates are found with the enzyme myrosinase (thioglucoside glucohydrolase, $E C$ 3.2.3.1). In the intact plant the enzyme is located in cellular compartments which are separated from the glucosinolates (Maheshwari et al. 1981). Crushing of seed and soaking in water (Schöne et al. 1994b) brings the myrosinase into contact with glucosinolates, resulting in almost complete disappearance of glucosinolates, isothiocyanates and further unstable glucosinolate degradation products. Effects of moist heat treatment and myrosinase activation in rapeseed products on animals seem to be unclear. In experiments of Münchmeyer et al. (1974) pigs avoided myrosinase-treated high-glucosinolate rapeseed meal diets. More recently in low-glucosinolate rapeseed products the glucosinolate degradation by endogenous myrosinase activation increased diet acceptance by rats (Dietz et al. 1991) or pigs (Schöne et al. 1994b).

Glucosinolates and glucosinolate degradation products impair the I status or increase I requirement. In East Germany pig diets containing high-glucosinolate rapeseed meal were not supplemented with I until 1986, and pigs suffered from hypothyroidism, i.e. cretinism, changed body proportions and shortened limbs, myxoedema and pronounced goitre (Lüdke \& Schöne, 1988). The National Research Council (1988) recommends $140 \mu \mathrm{g}$ (supplementary) $\mathrm{I} / \mathrm{kg}$ feed for growing pigs. The question remains whether this amount of $\mathrm{I}$ meets requirements in the case of rapeseed feeds.

The objective of the present experiments was to evaluate the pig response to increasing dietary glucosinolate content combined with different concentrations of $I$. The glucosinolate content of diets was varied either by changing the proportion of ground rapeseed or rapeseed press cake, or by moist heat treatment. Animal response criteria were the feed intake and live-weight gain, the serum concentrations of thyroid hormone and thiocyanate $\left(\mathrm{SCN}^{-}\right)$and the weight and I content of the thyroid.

\section{MATERIALS AND METHODS}

\section{Rapeseed and rapeseed press cake tested}

Rapeseed, winter cultivar 'Madora', breeder Saatzucht Hans Lembke GmbH Malchow, Poel, Germany, contained on a DM basis $224 \mathrm{~g}$ crude protein $/ \mathrm{kg}, 444 \mathrm{~g}$ ether extract $/ \mathrm{kg}$ and $89 \mathrm{~g}$ crude fibre $/ \mathrm{kg}$.

Rapeseed press cake, winter cultivar 'Falcon', breeder Norddeutsche Pflanzenzucht Hans Georg Lembke KG Hohenlieth, Germany, was pressed in a screw press (Reinartz Neuss, Germany, Type AP 10/06). Feed contained $321 \mathrm{~g}$ crude protein, $180 \mathrm{~g}$ ether extract and $102 \mathrm{~g}$ crude fibre $/ \mathrm{kg}$ DM. According to digestibility experiments this rapeseed press cake provided 14.1 MJ metabolizable energy (ME) $/ \mathrm{kg} \mathrm{DM}$, similar to the energy content of barley (Lüdke \& Schöne, 1994).

Rapeseed and rapeseed press cake, both untreated, contained 20 and $18.5 \mathrm{mmol}$ glucosinolates/kg DM (Table 1) respectively. Moist heat treatment has already been described in a previous paper (Schöne et al. 1994b). Crushed rapeseed and rapeseed press cake were soaked in tap water $\left(1 \mathrm{litre} / \mathrm{kg}\right.$ ) for $2 \mathrm{~h}$. Subsequently, the mash was dried at $60^{\circ}$ 
Table 1. Glucosinolate concentrations in rapeseed (RS) and rapeseed press cake $(R P C)(\mathrm{mmol} /$ $k g D M)$, untreated or moist-heat treated, tested in pig experiments

\begin{tabular}{|c|c|c|c|c|}
\hline Experiment... & $\begin{array}{c}1 \\
\text { RS* untreated }^{*}\end{array}$ & $\begin{array}{c}2 \\
\mathrm{RPC} \dagger \text { untreated }\end{array}$ & $\begin{array}{c}3 \\
\text { RS* soaked } \ddagger \text { and dried }\end{array}$ & $\begin{array}{c}4 \\
\text { RPC } \dagger \text { soaked } \ddagger \text { and dried }\end{array}$ \\
\hline Gluconapin & 4.0 & $3 \cdot 1$ & 0.4 & ND \\
\hline Glucobrassicanapin & $1 \cdot 3$ & 0.6 & 0.1 & ND \\
\hline Progoitrin & $10 \cdot 8$ & 7.3 & 1.2 & $0 \cdot 1$ \\
\hline Pronapoleiferin & $0 \cdot 2$ & 0.2 & ND & ND \\
\hline 4-Hydroxy-glucobrassicin & 2.9 & 4.7 & $0 \cdot 2$ & 0.2 \\
\hline Glucobrassicin & 0.1 & 0.3 & ND & $\mathrm{ND}$ \\
\hline Neoglucobrassicin & 0.1 & 0.1 & ND & ND \\
\hline Others§ & 0.5 & 2.2 & 0.2 & ND \\
\hline Total & 19.9 & 18.5 & $2 \cdot 1$ & 0.3 \\
\hline
\end{tabular}

ND, not detectable $(<0.1 \mathrm{mmol} / \mathrm{kg} \mathrm{DM})$.

* Winter cultivar 'Madora' (one batch).

† Winter cultivar 'Falcon' (one batch).

$\ddagger$ Crushed RS or RPC $(1 \mathrm{~kg})$ was soaked with 1 litre water in a feed mixer and the mash dried to constant weight at $60^{\circ}$ $\S$ Glucoraphanin, glucoallysin, gluconasturtiin and undetectable glucosinolates.

Treatment drastically decreased the glucosinolate content. Glucosinolate degradation products could not be detected in treated rapeseed and rapeseed press cake.

\section{Animals and diets}

Four experiments with a total of ninety-eight crossbred pigs (Piétrain $\times$ German Landrace $\times$ Large White) were carried out. In Expts 1 and 2 dietary proportions of rapeseed products up to $150 \mathrm{~g} / \mathrm{kg}$ were compared with control diets without rapeseed products. In Expts 3 and $4150 \mathrm{~g}$ moist-heat-treated rapeseed products $/ \mathrm{kg}$ diet were tested against untreated material. Rapeseed and rapeseed press cake used were the same as in Expts 1 and 2. Ultimately the groups fed with $150 \mathrm{~g}$ (untreated) rapeseed products/kg diet from Expts 1 and 2 served as controls for groups receiving this content of rapeseed products treated in Expts 3 and 4. After weaning at 5 weeks of age, the piglets were selected from a total of forty litters and transferred from the pig farm (Gleißberg agrar Golmsdorf, Germany) to the animal nutrition research unit in Remderoda, Germany. For 6 weeks before the experiments, the piglets received a grain-soyabean meal-whey diet (no fishmeal) containing $195 \mathrm{~g}$ crude protein, $13 \mathrm{MJ}$ ME, $11 \mathrm{~g}$ lysine and $150 \mu \mathrm{g} \mathrm{I} / \mathrm{kg}$ feed.

At the start of the experiments the pigs were randomized with respect to body weight, sex and litter. All pigs were held under the same conditions in individual pens (temperature $17-22^{\circ}$, relative air humidity $50-80 \%$ ), with free access to feed and water. Design and procedures of these animal experiments were approved by the Official Commission for Animal Experimentation (permission of Thuringian Ministry of Health and Welfare dated 18 March 1991).

\section{Expt 1}

Forty pigs (twenty female and twenty male castrated) with an initial body weight of 31.5 (SE 0.36) kg were randomly allocated to ten homogeneous groups each consisting of two female and two male castrated pigs from different litters (Table 2; groups 1-10). For a period of $105 \mathrm{~d}$ eight animals each received diets without oilseed (groups 1 and 2), with 
Table 2. Composition of rapeseed diets tested in Expt $\mathrm{l}^{*}$ and Expt $3 \dagger(\mathrm{g} / \mathrm{kg}$ diet)

\begin{tabular}{|c|c|c|c|c|c|c|}
\hline Group $\$ \ldots$ & $1+2$ & $3+4$ & $5+6$ & $7+8$ & $9+10$ & $11+12$ \\
\hline \multicolumn{7}{|l|}{ Ingredients } \\
\hline Soyabean meal, solvent-extracted ( $430 \mathrm{~g}$ crude protein $/ \mathrm{kg}$ ) & 140 & - & 128 & 116 & 102 & 102 \\
\hline Soyabean, toasted & - & 200 & - & - & - & - \\
\hline Rapeseed, untreated & - & - & 50 & 100 & 150 & - \\
\hline Rapeseed, treated§ & - & - & - & - & - & 150 \\
\hline Barley & 415 & 385 & 396 & 377 & 359 & 359 \\
\hline Wheat & 415 & 385 & 396 & 377 & 359 & 359 \\
\hline Mineral and vitamin premix $\|$ & 30 & 30 & 30 & 30 & 30 & 30 \\
\hline \multicolumn{7}{|l|}{ Composition } \\
\hline DM & 874 & 872 & 870 & 871 & 876 & 879 \\
\hline Crude protein & 174 & 178 & 178 & 180 & 174 & 179 \\
\hline Metabolizable energy $(\mathrm{MJ} / \mathrm{kg})$ & $12 \cdot 7$ & $13 \cdot 3$ & $13 \cdot 0$ & 13.2 & 13.5 & 13.6 \\
\hline
\end{tabular}

* Groups 1-10.

$\dagger$ Groups 9-12.

$\ddagger$ Groups $1,3,5,7,9$ and 11 received $125 \mu \mathrm{g}$ supplementary $\mathrm{l} / \mathrm{kg}$ diet; groups $2,4,6,8,10$ and 12 received $250 \mu \mathrm{g}$ supplementary I/kg diet.

$\S$ Treatment described in Table 1.

\| Supplementation per $\mathrm{kg}$ diet: lysine $1.5 \mathrm{~g}$, Ca $4 \mathrm{~g}, \mathrm{P} 1.3 \mathrm{~g}, \mathrm{Na} 1.1 \mathrm{~g}, \mathrm{Cu} 20 \mathrm{mg}, \mathrm{Zn} 60 \mathrm{mg}$, Se $0.15 \mathrm{mg}$, retinol equivalents (as coated retinyl ester preparation) $1.35 \mathrm{mg}$, cholecalciferol $14 \mu \mathrm{g}, \alpha$-tocopherol (as $\alpha$-tocopheryl acetate preparation) $15 \mathrm{mg}$, cobalamin $15 \mu \mathrm{g}$.

I Calculated according to the Deutsche Landwirtschaftsgesellschaft (1991) feed table and Lüdke \& Schöne (1994).

$200 \mathrm{~g}$ toasted soyabeans $/ \mathrm{kg}$ (groups 3 and 4), or with rapeseed, $50 \mathrm{~g} / \mathrm{kg}$ (groups 5 and 6), $100 \mathrm{~g} / \mathrm{kg}$ (groups 7 and 8 ) or $150 \mathrm{~g} / \mathrm{kg}$ (groups 9 and 10). The odd-numbered groups 1, 3, 5 7 and 9 were given the recommended I dose $(125 \mu \mathrm{g}$ supplementary I/kg diet), whereas the even-numbered groups $2,4,6,8$ and 10 were given double the recommended dose $(250$ $\mu \mathrm{g}$ supplementary I/kg diet). In basal diets levels of less than $60 \mu \mathrm{g} \mathrm{I} / \mathrm{kg}$ were detected. I was provided by KI bound to casein. This preparation was found to be highly stable (Groppel, 1986). In the diets with $125 \mu \mathrm{g}$ supplementary $\mathrm{I} / \mathrm{kg}$ total I concentrations from $90 \mu \mathrm{g} / \mathrm{kg}$ (group 1) to $130 \mu \mathrm{g} / \mathrm{kg}$ diet (group 9) were detected. In the diets with $250 \mu \mathrm{g}$ supplementary $\mathrm{I} / \mathrm{kg}$, the determined total I concentrations ranged from $180 \mu \mathrm{g} / \mathrm{kg}$ diet (group 10) to $230 \mu \mathrm{g} / \mathrm{kg}$ diet (group 2).

\section{Expt 2}

In the $111 \mathrm{~d}$ feeding experiment eight homogeneous groups of five pigs each (each group consisting of three female and two male castrated pigs from different litters) with a mean initial body weight of 22.5 (SE 0.25 ) $\mathrm{kg}$ received diets with an increasing rapeseed press cake content (Table 3, groups 1-8). The same amounts of $\mathrm{ME}$ as well as crude protein and lysine were calculated for all groups $(12.4 \mathrm{MJ} / \mathrm{kg}, 154 \mathrm{~g} / \mathrm{kg}$ and $8.5 \mathrm{~g} / \mathrm{kg}$ diet respectively). Pigs of odd-numbered groups $1,3,5$ and 7 received $125 \mu \mathrm{g}$ supplementary $\mathrm{I} / \mathrm{kg}$ diet; pigs of even-numbered groups $2,4,6$ and 8 were given $250 \mu \mathrm{g}$ supplementary I/kg diet. The I content of basal diets was the same as in Expt 1 . In the low I dosage groups $(125 \mu \mathrm{g} / \mathrm{kg}$ diet) the amount of I recovered ranged from 140 (group 7) to $170 \mu \mathrm{g} / \mathrm{kg}$ diet (group 5), and in the high I dosage groups (250 diet) from 260 (group 8) to $330 \mu \mathrm{g} / \mathrm{kg}$ diet (group 4). 
Table 3. Composition of rapeseed press cake diets tested in Expt $2 *$ and Expt $4 \dagger(\mathrm{g} / \mathrm{kg} \mathrm{diet}) \ddagger$

\begin{tabular}{|c|c|c|c|c|c|}
\hline Group $\$ . .$. & $1+2$ & $3+4$ & $5+6$ & $7+8$ & $9+10$ \\
\hline \multicolumn{6}{|l|}{ Ingredients } \\
\hline Soyabean meal $(430 \mathrm{~g}$ crude protein $/ \mathrm{kg})$ & 150 & 122 & 95 & 66 & 66 \\
\hline Rapeseed oil & 5 & - & - & - & - \\
\hline Rapeseed cake, untreated & - & 50 & 100 & 150 & - \\
\hline Rapeseed cake, treated $\|$ & - & - & - & - & 150 \\
\hline Barley & 815 & 798 & 775 & 754 & 754 \\
\hline Mineral and vitamin premix & 30 & 30 & 30 & 30 & 30 \\
\hline \multicolumn{6}{|l|}{ Composition } \\
\hline $\mathrm{DM}$ & 860 & 858 & 861 & 861 & 865 \\
\hline Crude protein & 167 & 166 & 170 & 169 & 172 \\
\hline
\end{tabular}

* Groups 1-8.

+ Groups 7-10.

$\ddagger$ Metabolizable energy was calculated as $12.4 \mathrm{MJ} / \mathrm{kg}$ diet according to the Deutsche Landwirtschaftsgesellschaft (1991) feed table and Lüdke \& Schöne (1994).

$\S$ Groups $1,3,5,7$ and 9 received $125 \mu \mathrm{g}$ supplementary $\mathrm{I} / \mathrm{kg}$ diet; groups 2, 4, 6, 8 and 10 received $250 \mu \mathrm{g}$ supplementary $\mathrm{I} / \mathrm{kg}$ diet.

\| Treatment described in Table 1.

I Supplementation per kg diet: lysine $1.5 \mathrm{~g}$, Ca $4 \mathrm{~g}, \mathrm{P} 1.3 \mathrm{~g}, \mathrm{Na} 1.1 \mathrm{~g}, \mathrm{Cu} 20 \mathrm{mg}, \mathrm{Zn} 60 \mathrm{mg}$, Se $0.15 \mathrm{mg}$, retinol equivalents (as coated retinyl ester preparation) $1.35 \mathrm{mg}$, cholecalciferol $14 \mu \mathrm{g}$, $\alpha$-tocopherol (as $\alpha$-tocopheryl acetate preparation) $15 \mathrm{mg}$, cobalamin $15 \mu \mathrm{g}$.

\section{Expts 3 and 4}

The experiments were carried out with a total of thirty-six pigs of which eighteen had already been used in Expts 1 and 2. Moist-heat-treated rapeseed and rapeseed press cake were each fed at a level of $150 \mathrm{~g} / \mathrm{kg}$ diet (Table 2, groups 11 and 12; Table 3, groups 9 and 10 ), corresponding to the groups receiving the largest quantity of untreated rapeseed (Table 2 , groups 9 and 10) and rapeseed press cake (Table 3, groups 7 and 8 ) in their diets. The DM and crude nutrient contents of treated rapeseed or rapeseed press cake were similar to those of untreated feed. Duration of experiments, genetics, sex of animals, I dosages and I recovery were similar to those in Expts 1 and 2 (Table 2, Table 3).

\section{Investigation criteria, samples and analyses}

Glucosinolates of rapeseed (Expt 1, Expt 3) and rapeseed press cake (Expt 2, Expt 4) were detected by HPLC with sinigrin as internal standard (European Community, 1990). Aglucones were determined by temperature programmed GC and mass spectrometry with phenylisothiocyanate as internal standard (Lange et al. 1986). I content of feed ingredients and diets was measured by the method of Sandell \& Kolthoff (1937) with $\mathrm{HCl}-\mathrm{HClO}_{4}$ ashing and further modifications introduced by Gstrein et al. (1979).

The pigs were weighed once fortnightly and feed intake was recorded. The thyroid was removed at slaughter. The organ was weighed and frozen in a polyethylene bag at $-20^{\circ}$. Blood was sampled from the anterior vena cava on day 56, and on the penultimate day in Expts 1 and 3 after a $12 \mathrm{~h}$ fasting period. The same procedure as for day 56 was adopted in Expts 2 and 4, however, at the end of the experiments blood was sampled in the slaughterhouse after a $20 \mathrm{~h}$ fasting period. Blood samples were transferred to glass tubes, centrifuged after $2 \mathrm{~h}$ for $15 \mathrm{~min}$ at $1600 \mathrm{~g}$ and the serum frozen at $-20^{\circ}$ until analysed. 
The $\mathrm{T}_{4}$ and $\mathrm{T}_{3}$ concentrations in serum were measured by radioimmunoassay (RIA Kit Hennig, Berlin, Germany), and the $\mathrm{SCN}^{-}$concentration by HPLC (Rudolph 1993).

Thyroidal I was measured according to the method of Tiran et al. (1991). Lyophilized ground thyroid 4-6 mg (Laboratory scale RC 210 P, Sartorius, Göttingen, Germany) was ashed with $\mathrm{NaClO}_{3}$ (Merck, Darmstadt, Germany, no. 6423) and $\mathrm{HClO}_{4}$ (Merck no. 519) dissolved in distilled deionized water by an $\mathrm{Al}$ thermoblock $\left(100^{\circ}, 25 \mathrm{~min}\right)$. Arsenite reduction solution $\left(\mathrm{NaAsO}_{2}\right.$, Merck no. 6287) was added to samples and to standards (ashing solution blank or 5, 10, 20 and $30 \mathrm{ng} \mathrm{I/ml} \mathrm{as} \mathrm{KIO}_{3}$, Merck no. 5051). Application of $\mathrm{Ce}\left(\mathrm{SO}_{4}\right)_{2}$ (Merck no. 9092) induces the so-called Sandell-Kolthoff reaction: As (III) oxidizing to As (V) reduces Ce (IV) to Ce (III). I catalyses the decolorization of Ce (IV), which is detected photometrically at $405 \mathrm{~nm}$ ('Specol 11', Carl Zeiss, Jena, Germany).

\section{Statistical methods}

All data were analysed with the Statistical Analysis Systems software package (SAS 6.11, SAS Institute, Heidelberg, Germany). The results are given as means with their (pooled) standard error. Data were analysed by two-way ANOVA with the variables dietary glucosinolate content, I dosage and interaction. Group means were compared using the Newman-Keuls test (Steel \& Torrie, 1980).

\section{RESULTS}

\section{Rapeseed (Expt 1)}

Pigs receiving the highest level of rapeseed $(150 \mathrm{~g} / \mathrm{kg}$ diet $)$ showed the lowest feed intake (Table 4). According to the Newman-Keuls test, however, all differences between group means were below the minimum significant difference of $0.35 \mathrm{~kg}$ daily feed intake. Weight gain followed energy intake. In the controls receiving solvent-extracted soyabean the lower weight gain resulted from the lower ME content of this oilseed-free diet (Table 2); in pigs receiving the highest rapeseed level $(P<0.05$ only with $250 \mu \mathrm{g}$ supplementary $\mathrm{I} / \mathrm{kg}$ diet $)$ it was caused by the decreased feed intake (Table 4$)$.

The feed:gain ratio of pigs receiving control diets containing solvent-extracted soyabean meal was increased $(P<0.05$ with $125 \mu \mathrm{g}$ supplementary $\mathrm{I} / \mathrm{kg}$ diet $)$ due to lower ME (Table 2).

There was a drastic increase in serum $\mathrm{SCN}^{-}$concentration due to rapeseed in the diet. Comparing the $\mathrm{SCN}^{-}$response to $50 \mathrm{~g}$ rapeseed $/ \mathrm{kg}$ diet and to $150 \mathrm{~g}$ rapeseed $/ \mathrm{kg}$ diet, the threefold intake only doubled $\mathrm{SCN}^{-}$serum concentration. This indicates a lower glucosinolate degradation or better $\mathrm{SCN}^{-}$elimination with higher quantities of glucosinolates.

At each blood sampling, the I dosage was found to have affected the serum $T_{4}$ concentration significantly. In the twenty animals receiving $125 \mu \mathrm{g}$ supplementary $\mathrm{I} / \mathrm{kg}$ diet, serum $\mathrm{T}_{4}$ levels of 43 (SE 1.8) nmol/1 and 48 (SE 2.1) nmol/l were found at day 56 and day 105 respectively, whereas in those receiving $250 \mu \mathrm{g}$ supplementary $\mathrm{I} / \mathrm{kg}$ diet serum $\mathrm{T}_{4}$ levels reached 51 (SE 1.8) $\mathrm{nmol} / \mathrm{l}$ and 57 (SE 1.9) nmol/l respectively. The decrease of serum $\mathrm{T}_{4}$ concentration occurred primarily with diets containing at least $100 \mathrm{~g}$ rapeseed $/ \mathrm{kg}$. At day 105 the difference in serum $\mathrm{T}_{4}$ concentration between the low and high I dosage groups was highly significant in the animals receiving at least $100 \mathrm{~g}$ rapeseed $/ \mathrm{kg}$ diet.

The serum $\mathrm{T}_{3}$ concentration responded to dietary $\mathrm{I}$ and glucosinolates significantly only at day 56 . The highest serum $\mathrm{T}_{3}$ concentration was found in pigs with 100 or $150 \mathrm{~g}$ $\mathrm{rapeseed} / \mathrm{kg}$ diet with low I dosage. 


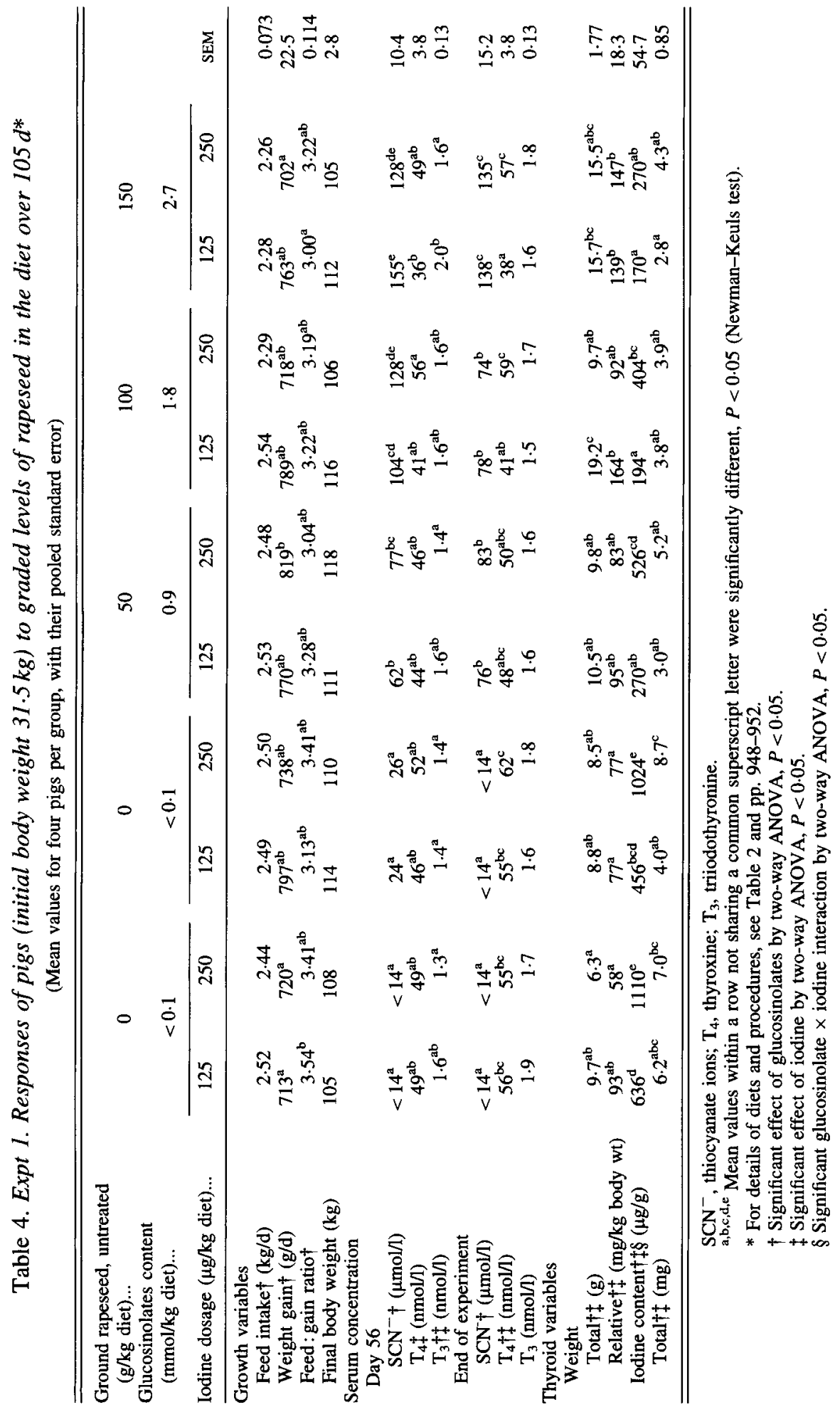


A dietary level of $100 \mathrm{~g}$ rapeseed $/ \mathrm{kg}$ increased thyroid weight significantly, particularly in animals receiving a low I dosage. In the group receiving $150 \mathrm{~g}$ rapeseed $/ \mathrm{kg}$ diet, the thyroid weight was increased irrespective of I dosage or treatment. The I concentration in thyroid tissue varied between groups from $<200 \mu \mathrm{g} / \mathrm{g}$ to $>1000 \mu \mathrm{g} / \mathrm{g}$. Rapeseed or glucosinolates enlarged the organ, resulting in a dilution effect, leading to a lower I concentration in the thyroid.

In total thyroid the deposition of I was significantly decreased by glucosinolates indicating a higher fall of I concentration than degree of thyroid enlargement. The 250 $\mu \mathrm{g} \mathrm{I} / \mathrm{kg}$ diet dosage led to significantly higher deposition of I in the thyroid than the dosage of $125 \mu \mathrm{g} \mathrm{I} / \mathrm{kg}$ diet.

\section{Rapeseed press cake (Expt 2)}

Neither the amount of press cake in feed, nor the I dosage had a significant effect on feed intake, daily live-weight gain or feed efficiency (Table 5).

As in Expt 1, dietary glucosinolates led to increased serum $\mathrm{SCN}^{-}$concentrations (Table 5). Also in Expt 2 (Table 5) the $\mathrm{SCN}^{-}$response did not markedly depend on the quantity of the rapeseed product applied. In blood samples taken at slaughter (day 111) serum $\mathrm{SCN}^{-}$concentration was hardly increased by rapeseed press cake and no difference was found between groups with different quantities of rapeseed press cake in their diets. Possibly, the longer period of feed withdrawal lowered glucosinolates in the intestines and blood. The significantly higher serum $\mathrm{SCN}^{-}$concentration of the low I group points to retarded $\mathrm{SCN}^{-}$elimination, i.e. excretion.

As in Expt 1 (Table 4), in Expt 2 (Table 5) glucosinolates decreased and supplementary $\mathrm{I}$ increased serum $\mathrm{T}_{4}$ concentration.

At day 56, the serum $\mathrm{T}_{3}$ concentration decreased due to a high proportion of rapeseed press cake in the diet $(150 \mathrm{~g} / \mathrm{kg}$ diet), in contrast to Expt 1 (Table 4), where dietary glucosinolates increased serum $\mathrm{T}_{3}$ concentration at the first blood sampling. Increasing amounts of rapeseed press cake significantly increased the weight of the thyroid (Table 5). The I-dosage effect of Expt 1 (Table 4) was not confirmed.

I concentration and total thyroidal I deposition responded significantly to I administration and rapeseed press cake (Table 5). There was no difference in total thyroidal I content between the different rapeseed press cake groups.

\section{Moist heat treatment of rapeseed (Expt 3) and rapeseed press cake (Expt 4)}

In Expt 3 ANOVA showed that the effect of treatment, i.e. glucosinolate loss, on feed intake and weight gain was significant (Table 6). Weight gain diminution was significant only in the group receiving untreated rapeseed and $250 \mu \mathrm{g}$ supplementary $\mathrm{I} / \mathrm{kg}$. However, this significant result with the higher I dosage seems to be an artefact. In Expt 4 no effect of diets on feed intake, growth intensity and feed: gain ratio was detected.

Treatment of rapeseed and rapeseed press cake hardly affected the serum SCN concentration at all. There was a significantly lower $\mathrm{SCN}^{-}$concentration due to lower glucosinolate intake only at day 56 in Expt 3; in Expt 4 there was a tendency towards this $(P=0.07)$ at slaughter. At this blood sampling the I dosage influenced the serum $\mathrm{SCN}^{-}$status significantly. An increased serum $\mathrm{SCN}^{-}$concentration in pigs receiving the lower I dosage was also found in Expt 2 (Table 5).

The higher I dosage significantly increased the serum $\mathrm{T}_{4}$ concentration at each time of blood sampling (Table 6). The response of $\mathrm{T}_{4}$ concentration to dietary glucosinolate level 
F. SCHÖNE $E T A L$.

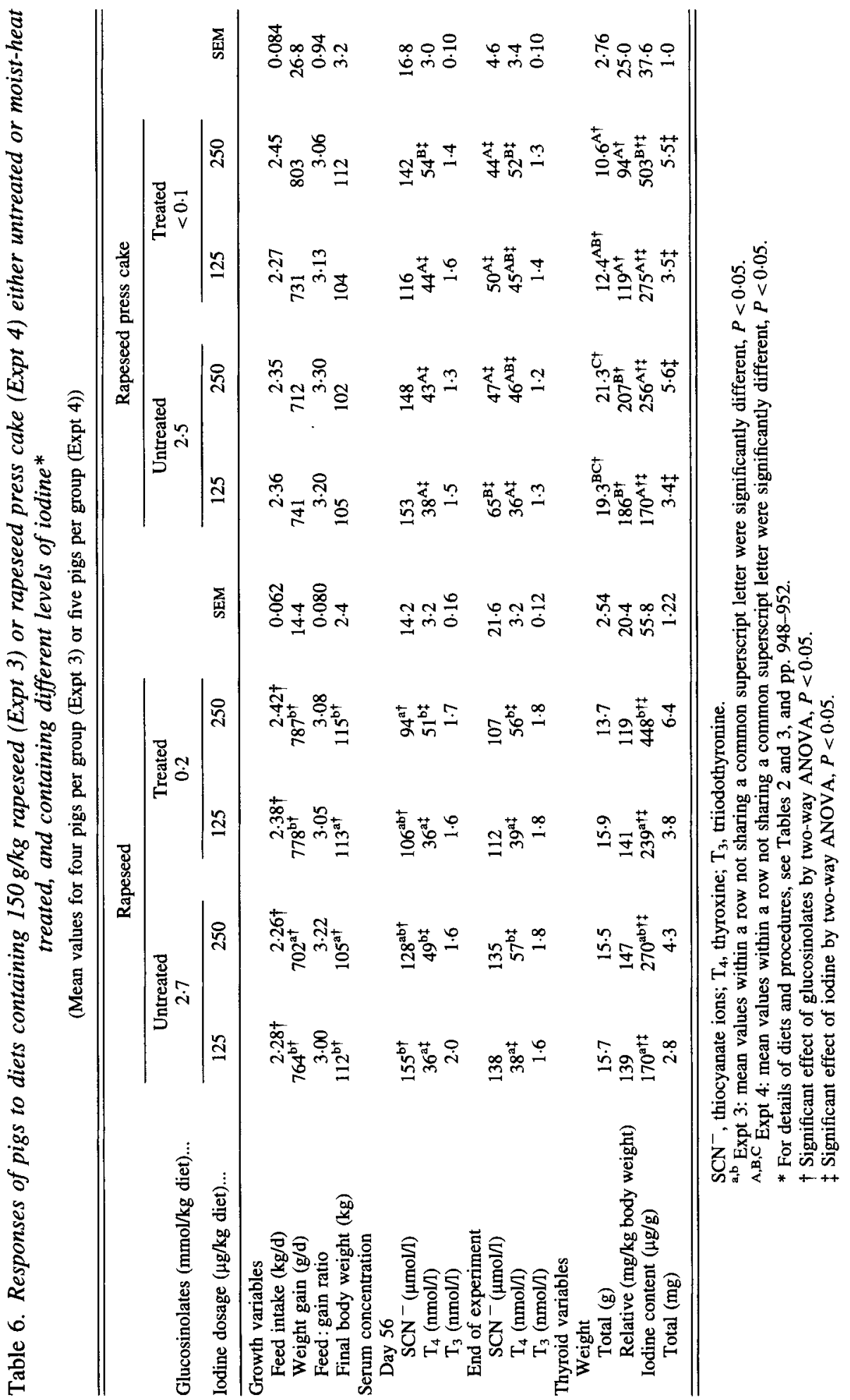


was significant only in Expt 4 at both blood sampling times. Glucosinolates and I did not affect $\mathrm{T}_{3}$ status. There was a tendency towards higher serum $\mathrm{T}_{3}$ concentrations in the low $\mathrm{I}$ dosage groups in Expt 4 (day 56, $P=0.06$ ).

In Expt 4 thyroid weight corresponded to dietary glucosinolate content. No effect of glucosinolates on the weight of the thyroid could be detected in Expt 3. In neither of the two experiments did the I dosage influence thyroid weight.

Both dietary glucosinolate content and I dosage had a significant effect on thyroidal I concentration. The total thyroidal I content was only affected by the I dosage (Expt 3 tendency $P=0 \cdot 10$, Expt $4 P=0 \cdot 04$ ). The thyroidal I store did not reflect different glucosinolate intakes.

\section{DISCUSSION}

The glucosinolate content of rapeseed used (Table 1, Expt 1) was somewhat above $30 \mathrm{mmol} / \mathrm{kg}$ defatted air-dried matter (basis $910 \mathrm{~g} / \mathrm{kg} \mathrm{DM}$ ) which is the borderline of 00 rapeseed quality proposed already some time ago (Fenwick, 1984). However, among the winter rapeseed types now grown in East Germany, it belongs to the top $30 \%$ in terms of glucosinolate content.

The rapeseed press cake used in Expt 2 (Table 1) contained less glucosinolates $/ \mathrm{kg}$ defatted DM than rapeseed used in Expt 1.

The rapeseed from which the rapeseed press cake was made contained $14.4 \mathrm{mmol}$ glucosinolates $/ \mathrm{kg}$ DM. Pressing one quarter of the seed as fat (ether extract of DM: rapeseed $437 \mathrm{~g} / \mathrm{kg} \rightarrow$ rapeseed press cake $180 \mathrm{~g} / \mathrm{kg}$ ) resulted in a $28 \%$ increase in the glucosinolate content of the residue. The different fat contents of rapeseed and rapeseed press cake caused the differences in glucosinolate content. On a fat-free DM basis the glucosinolate contents of seed and cake were almost the same $(23.9$ and $22.6 \mathrm{mmol} / \mathrm{kg}$ respectively).

Moreover, in further investigations, pressing (Keith \& Bell, 1991) or grinding (Schöne et $a l .1994 b$ ) of rapeseed did not decisively change the glucosinolate content on a fat-free basis. Addition of water causes degradation of glucosinolates, most probably by activation of endogenous myrosinase. After heat drying, isothiocyanates become volatile. These and further glucosinolate degradation products (nitriles, oxazolidinethiones) were not detectable in moist-heat-treated ground rapeseed and rapeseed press cake (Table 1).

\section{Dose responses}

Feed intake and growth. Looking at the experiments with graded rapeseed or rapeseed cake content, only in Expt 1 did the group receiving the highest level of rapeseed $(150 \mathrm{~g} / \mathrm{kg}$ diet) show lower feed intake and growth intensity compared with the group receiving $50 \mathrm{~g} / \mathrm{kg}$ diet. There was a similar difference between these two rapeseed cake levels (Expt 2) with regard to weight gain. However, this was not significant because of the higher variance of weight gain in this experiment (Expt 2) than in Expt 1, presumably due to the more difficult adaptation of initially lighter animals to the grower diet in Expt 2.

Undoubtedly glucosinolates affect feed intake and growth; as a rule $>10 \mathrm{mmol} / \mathrm{kg} \mathrm{diet}$ resulted in significant impairments in pig experiments (Lüdke \& Schöne, 1988). At such dietary levels, glucosinolates definitely act as toxicants. Additional I or thyroid hormone administration is without any effect (Schöne et al. 1990; Spiegel et al. 1993). Feed intake and growth are restored only by decreasing the glucosinolate load. The response of animals to diets with a lower glucosinolate content is uncertain. Contrary to the results obtained in 
Expt 1, in an earlier pig experiment rapeseed meal diet containing $6 \mathrm{mmol}$ glucosinolates/ $\mathrm{kg}$ had no effect on feed intake and growth (Schöne $e t$ al. 1991b). Production of rapeseed meal includes a desolventizing-toasting step. This steam heat treatment at least partially destroys sinapine, tannins and possibly further unfavourable substances in rapeseed meal. In rapeseed or rapeseed press cake these substances are present, and together with minor quantities of glucosinolates they could reduce feed intake.

There are some efforts to attribute the lower feed intake to bitter taste and pungent odour of glucosinolate cleavage products. Indeed, human subjects detect bitterness in 'traces' of glucosinolates (Fenwick et al. 1983). In preference tests pigs offered rapeseed meal diets whose glucosinolate content differed only by $1 \mathrm{mmol} / \mathrm{kg}$, selected the one with the lower dietary glucosinolate level (Schöne et al. 1991a). According to these findings, animals perceive very small quantities of glucosinolates. But this ability has no consequence under normal circumstances and the present experimental conditions, in which animals received one type of feed only and maintained a level of feed intake and growth despite the higher dietary glucosinolate concentration (Bille et al. 1983; Rundgren, 1983; Schöne et al. 1991b).

Serum thiocyanate concentration. In accordance with the findings of earlier experiments with rapeseed meal on different animal species (Paik et al. 1980; Schöne et al. 1990), rapeseed and rapeseed press cake drastically increased the serum $\mathrm{SCN}^{-}$ concentration. There are two sources of $\mathrm{SCN}^{-}$. First, $\mathrm{SCN}^{-}$is a minor product of glucosinolate degradation by microbial thioglucosidases in the intestine (Oginsky $e t$ al. 1965). Second, nitriles from glucosinolate degradation release $\mathrm{CN}^{-}$, which is detoxified by thiosulfate $\mathrm{S}$ transferases (rhodanese, $E C$ 2.8.1.1) forming $\mathrm{SCN}^{-}$.

In the present and in earlier experiments (Tables 4, 5 and 6; Schöne et al. 1990) no reproducible dose-response effect of dietary glucosinolate level on serum $\mathrm{SCN}^{-}$ concentration was detected. A better dose relationship was found between glucosinolate intake and urinary $\mathrm{SCN}^{-}$excretion (Schöne \& Paetzelt, 1987). In these balance experiments with pigs, up to $9 \%$ of molar glucosinolate intake was found as $\mathrm{SCN}^{-}$in urine. Further metabolites of glucosinolate degradation (i.e. detoxication), hippuric acid and phenyl acetic acid, were detected in the urine of rats (Lange et al. 1992).

Serum thyroid hormone concentration, weight and iodine content of thyroid. In the present experiment and in earlier experiments with pigs (Schöne et al. 1990, 1991a,b) glucosinolates decreased serum $\mathrm{T}_{4}$ concentration, whereas I increased it. Even at the highest dietary glucosinolate levels tested (Expt 1: $2.7 \mathrm{mmol} / \mathrm{kg} \mathrm{diet}$, Expt 2: $2.5 \mathrm{mmol} / \mathrm{kg}$ diet) the decrease of serum $T_{4}$ concentration could be prevented (Table 4) or retarded (Table 5) by more I. In earlier pig experiments (Schöne et al. 1990) with rapeseed meal diets containing $10 \mathrm{mmol}$ glucosinolates $/ \mathrm{kg}$, at least $500 \mu \mathrm{g}$ supplementary $\mathrm{l} / \mathrm{kg}$ diet was required to bring the serum $\mathrm{T}_{4}$ concentration to the level found in glucosinolate-free controls. However, exceedingly high dietary glucosinolate levels prevent sustained thyroidal hormone production, thereby lowering serum $\mathrm{T}_{4}$ concentration despite administration of high I doses. Thus $1000 \mu \mathrm{g}$ supplementary $\mathrm{I} / \mathrm{kg}$ diet could not compensate for the fall in serum $\mathrm{T}_{4}$ concentration caused by $19 \mathrm{mmol}$ glucosinolates $/ \mathrm{kg}$ diet (Schöne et al. 1991a).

Serum $\mathrm{T}_{3}$ concentration was less affected or unaffected by dietary glucosinolates and $\mathrm{I}$ dosage in the present and in earlier experiments (Schöne et al. 1990, 1991a). The source of $T_{3}$ is $T_{4}$ which is deiodized mainly in the liver and peripheral tissue. There are findings of an elevated serum $\mathrm{T}_{3}$ concentration due to I deficiency or antithyroid agents. As described for the rat (Rognoni et al. 1982) or chicken (Schöne et al. 1991a) the thyroid-stressed pig 
shifts the production of $T_{4}$ to that of $T_{3}$. $T_{3}$ is more potent than $T_{4}$ and $T_{3}$ has one $I$ atom less than $T_{4}$ so that preference for $T_{3}$ spares $I$.

The weight of the thyroid was shown to be a sensitive indicator of dietary glucosinolate levels (Tables 4 and 5). The lower I dosage $(125 \mu \mathrm{g} / \mathrm{kg}$ diet) seemed to be almost sufficient. In earlier pig and chicken experiments (Schöne et al. 1991a) with higher dietary glucosinolate levels $(0-19 \mathrm{mmol} / \mathrm{kg})$ or I doses $(0-1000 \mu \mathrm{g} / \mathrm{kg}$ diet $)$, the effect of I in impeding an increase in thyroid weight or the development of goitre was significant.

Generally, grain diets without the addition of I or without inclusion of alternative I sources such as fishmeal, deplete the I store of the thyroid and produce goitre. Diets containing rapeseed and glucosinolates accelerate this process. More I counteracts these antithyroid effects, however, only up to a certain dietary glucosinolate level. In the present experiments $250 \mu \mathrm{g}$ supplementary $\mathrm{I} / \mathrm{kg}$ diet prevented thyroid enlargement of animals receiving up to about $1.5 \mathrm{mmol}$ glucosinolates $/ \mathrm{kg}$ diet (Tables 4 and 5). In pig experiments with rapeseed meal (Schöne et al. 1991b), the same I dosage counteracted the thyroid weight increase induced by an even higher dietary glucosinolate level $(2.4 \mathrm{mmol} / \mathrm{kg}$ diet $)$. This stronger antidotal effect of $I$ in rapeseed meal may be due to the fact that further goitrogenic agents are removed by toasting.

The effect of glucosinolates on thyroid weight may be explained by the impairment of iodide uptake, its oxidation to I, the I binding to thyroglobulin and synthesis as well as release of hormones, mainly $\mathrm{T}_{4}$. Impaired hormone production causes the pituitary to release thyroid-stimulating hormone (TSH) which increases the height of epithelial cells and the weight of the thyroid. It should be noted that in the present experiments glucosinolate-mediated thyroid enlargement might occur without a decrease of serum $\mathrm{T}_{4}$ concentrations. The TSH release and the effect on thyroid weight depend on the production of hormone. In tracer experiments in pigs, Ingram \& Evans (1980) affected the thyroid by altering the supply of dietary energy. Despite the production of different quantities of hormone, no effect on serum $T_{3}$ or $T_{4}$ concentration was detected.

Moist heat treatment of rapeseed and rapeseed press cake drastically diminished the content of glucosinolates and glucosinolate degradation products. However, the antithyroid action persisted, particularly in the case of rapeseed (Table 6). Heating of ground soaked rapeseed not only causes volatilization of isothiocyanates or nitriles, but also reacts with rapeseed amino acids to form thiourea and, possibly, other strong goitrogens (Langer \& Štolc, 1965). Diedrich \& Kujawa (1987) suggested some possible reactions of rapeseed matrix compounds with glucosinolate degradation products and reiterated the old demand to determine these antithyroid compounds in rapeseed products.

The highest thyroidal I deposit ( $\geq 1000 \mu \mathrm{g} \mathrm{I/g}$ fresh weight) was found in pigs receiving diets without glucosinolates (controls) with $250 \mu \mathrm{g}$ supplemental $\mathrm{I} / \mathrm{kg}$ diet, which confirms earlier findings (Schöne et al. 1990, 1991a). Glucosinolates reduced the thyroidal I deposition, whereas I increased it. The difference between tested dietary levels of glucosinolates was significant (Tables 4,5 , and 6).

In earlier experiments (Schöne et al. 1990, 1991a,b) very high glucosinolate levels (10-19 mmol/kg diet) lowered I deposition in the thyroid. Clearly, this statement applies to moderate or high I administration $(250 \mu \mathrm{g}-1000 \mu \mathrm{g}$ supplementary $\mathrm{I} / \mathrm{kg}$ diet). A lower I dosage causes a low thyroid I deposition even in diets without antithyroid compounds. The organism needs virtually all the I for hormone production, and storage is quite impossible.

The thyroid is the target of I but also of glucosinolate degradation products. The organ picks up I and oxidizes it via thyroid peroxidase to I, binding to tyrosyl residues. This thyroglobulin-bound I or the I of hormone or hormone precursor represents almost all I in 
the thyroid (Taurog, 1985). In the presence of glucosinolates, the action of thyroid peroxidase seems to be modified. According to an in vitro experiment by Kohler et al. (1988), the enzyme oxidizes oxazolidinethiones, representing important glucosinolate degradation products. This detoxication by thyroid peroxidase consumes elemental I; more exactly, iodine will be reduced to iodide which cannot be taken in by thyroglobulin. Glucosinolates, oxazolidinethiones and further glucosinolate degradation products limit the ability of peroxidase to oxidize iodide to I, resulting in lowering iodization of thyroglobulin and thyroid I deposition, respectively.

In conclusion, pig diets containing ground rapeseed or rapeseed press cake may contain up to $2 \mathrm{mmol}$ glucosinolates $/ \mathrm{kg}$. At least $250 \mu \mathrm{g}$ supplementary $\mathrm{I} / \mathrm{kg}$ diet is required to prevent a decrease of serum $\mathrm{T}_{4}$ concentration and thyroid enlargement. Moist heat treatment degrades glucosinolates in ground rapeseed or rapeseed press cake making it possible to incorporate as much as $150 \mathrm{~g} / \mathrm{kg}$ diet of such treated rapeseed feeds.

The authors wish to acknowledge the assistance of Mrs Carmen Kinast, Mrs Ingrid Löhnert, Mrs Elisabeth Blackburn and Mrs Heike Bergmann. This study was supported by the Federal Ministry of Nutrition, Agriculture and Forests, Bonn, Germany (project no. 93 4F 025).

\section{REFERENCES}

Bell, J. M. (1984). Nutrients and toxicants in rapeseed meal: a review. Journal of Animal Science 58, 996-1010. Bille, N., Eggum, B. O., Jacobson, I., Olsen, O. \& Sørensen, H. (1983). Antinutritional and toxic effects in rats of individual glucosinolates (+myrosinases) added to a standard diet. Zeitschrift für Tierphysiologie, Tierernährung und Futtermittelkunde 49, 195-210.

Bourdon, D. \& Aumaître, A. (1990). Low glucosinolate rapeseeds and rapeseed meals: effect of technological treatments on chemical composition, digestible energy content and feeding value for growing pigs. Animal Feed Science and Technology, 30, $175-191$.

Campbell, L. D. \& McDonald B. E. (1991). Summary of presentations on nutrition. In Rapeseed in a Changing World. Proceedings of the 8th International Rapeseed Congress, pp. 1923-1930 [D. I. McGregor, editor]. Saskatoon, Canada: University of Saskatchewan.

Deutsche Landwirtschaftsgesellschaft (1991). DLG-Futterwerttabellen Schweine. (DLG Feed Tables, Pigs), 6th ed. Frankfurt: DLG Verlag.

Diedrich, M. \& Kujawa, M. (1987). Degradation of progoitrin and its breakdown product VOT by microorganism of intestine of rats in vitro. In Proceedings of the 7th International Rapeseed Congress pp. 1710-1716 [J. Krzymanski, editor]. Poznan, Poland: Plant Breeding and Acclimatization Institute.

Dietz, H. M., Panigrahi, S. \& Harris, R. V. (1991). Toxicity of hydrolysis products from 3-butenyl glucosinolate in rats. Journal of Agricultural and Food Chemistry 39, 311-315.

European Community (1990). Oilseeds - determination of glucosinolates - high performance liquid chromatography. Official Journal of the European Commission. L 170, 27-34.

Fenwick, G. R. (1984). Rapeseed as an animal feedstuff - the problems and analysis of glucosinolates. Journal of the Association of Public Analysts 22, 117-130.

Fenwick, G. R., Griffiths, N. M. \& Heaney, R. K. (1983). Bitterness in brussels sprouts (Brassica oleracea L. var. gemmifera): the role of glucosinolates and their breakdown products. Journal of the Science of Food and Agriculture 34, 73-80.

Groppel, B. (1986). Jodmangelerscheinungen, Jodversorgung und Jodstatus des Wiederkäuers (Rind, Schaf, Ziege) (Iodine deficiency symptoms, iodine supply and iodine status of ruminants (cattle, sheep, goats)). Thesis B, University Leipzig, Germany.

Gstrein, H., Maichin, B., Eustacchio, P. \& Knapp, G. (1979). Eine mechanisierte katalytische Meßtechnik zur störungsfreien Bestimmung von Jodspuren in anorganischen und organischen Matrices (A mechanized catalytic detection principle for the accurate determination of trace iodine in inorganic and organic matrices). Mikrochimica Acta I, 291-302.

Ingram, D. L. \& Evans, S. E. (1980). Dependence of thyroxine utilization rate on dietary composition. British Journal of Nutrition 43, 525-531.

Keith, M. O. \& Bell, J. M. (1991). Composition and digestibility of canola press cake as a feedstuff for use in swine diets. Canadian Journal of Animal Science 71, 879-885. 
Kohler, H., Taurog, A. \& Dunford, H. B. (1988) Spectral studies with lactoperoxidase and thyroid peroxidase: interconversions between native enzyme, Compound II, and Compound III. Archives of Biochemistry and Biophysics 264, 438-439.

Lange, R., BaumgraB, R., Diedrich, M., Henschel, K.-P. \& Kujawa, M. (1992). Glucosinolate in der Ernährung Pro und Contra einer Naturstoffklasse. Teil II: Abbau und Stoffwechsel (Glucosinolates in nutrition - the pros and cons of a natural substance class. Part II: Degradation and metabolism). Ernährungsumschau 39, 292296.

Lange, R., Petrzika, M. \& Linow, F. (1986) Zur Kenntnis der Schwefelverbindungen in Raps- (Brassica napus) Varietäten und Verarbeitungsprodukten. 2. Mitt. Enzymatische Spaltung von Glucosinolaten, Isolierung und gaschromatographisch-massenspektrometrische Identifizierung der entstehenden Aglucone (Recognition of sulfur compounts in rapeseed (Brassica napus) varieties and products of processing. 2: Enzymic cleavage of glucosinolates, isolation and gas chromatographic mass spectrometric identification of arising aglucones). Die Nahrung 30, 1039-1042.

Langer, P. \& Stolc, V. (1965). Goitrogenic activity of allylisothiocyanate - a widespread natural mustard oil. Endocrinology 76, 151-155.

Lüdke, H. \& Schöne, F. (1988). Copper and iodine in pig diets with high glucosinolate rapeseed meal. I. Performance and thyroid hormone status of growing pigs fed on a diet with rapeseed meal treated with copper sulphate solution or untreated and supplements of iodine, copper or a quinoxaline derivative. Animal Feed Science and Technology 22, 33-43.

Lüdke, H. \& Schöne, F. (1994). Prüfung von Rapskuchen im Verdauungsversuch mit Schweinen (Testing of rapeseed cake in a digestibility experiment with pigs). In Alternativen in der Flächennutzung, der Erzeugung und Verwertung Landwirtschaftlicher Produkte. Proceedings of the 106th Kongress des Verbandes der Landwirtschaftlichen Untersuchungs- und Forschungsanstalten (VDLUFA), pp. 963-966 [H. Zarges, editor]. Darmstadt, Germany: VDLUFA Verlag.

McKinnon, P. J. \& Bowland, J. P. (1979). Effects of feeding low and high glucosinolate rapeseed meals and soybean meal on thyroid function of young pigs. Canadian Journal of Animal Science 59, 589-596.

Maheshwari, P. N., Stanley, D. W., Beveridge, T. J. \& Van de Voort, F. R. (1981). Localization of myrosinase (thioglucoside glucohydrolase, EC 3.2.3.1) in cotyledon cells of rapeseed. Journal of Food Biochemistry 5, 39-61.

Münchmeyer, R., Simon, O., Bergner, H., Huth, R. \& Wirthgen, B. (1974). Untersuchungen zur Fütterung von Rapsextraktionsschrot an monogastrische Tiere. 2. Mitt.: Einfluß von Rapsextraktionsschrot auf die Thyroxinsekretionsrate, einige Serum-Enzymaktivitäten und den Plasmaaminosäurengehalt beim Schwein (Studies on the feeding of extracted rapeseed meal to monogastric animals. 2: Effect of extracted rapeseed meal on the rate of thyroxine excretion, on the activities of some serum enzymes and on the level of plasma amino acids in pigs). Archiv für Tierernährung 24, 193-203.

National Research Council (1988). Nutrient Requirement of Swine. 9th ed. Washington, DC: National Academy of Science.

Oginsky, E. L., Stein, A. E. \& Greer, M. A. (1965). Myrosinase activity in bacteria as demonstrated by the conversion of progoitrin to goitrin. Proceedings of the Society of Experimental Biology and Medicine 119 , 360-364.

Paik, I. K., Robblee, A. R. \& Clandinin, D. R. (1980). The effect of sodium thiosulfate and hydroxo-cobalamin on rats fed nitrile-rich or goitrin-rich rapeseed meals. Canadian Journal of Animal Science 60, 1003-1013.

Rognoni, J. B., Lemarchand-Beraud, T., Berthier, C. \& Simon, C. (1982). Effect of long-term iodide refeeding on the synthesis and secretion of $\mathrm{T}_{3}, \mathrm{~T}_{4}$ and $\mathrm{TSH}$ in severe iodide deficient rats. Acta Endocrinologica 101, $377-385$.

Rowan, T. G. \& Lawrence, T. L. J. (1986). Ileal apparent digestibilities of amino acids, growth and tissue deposition in growing pigs fed low glucosinolate rapeseed meals. Journal of Agricultural Science, Cambridge 107, 493-504.

Rudolph, B. (1993). Zur Bestimmung von Thiocyanat im Serum mittels HPLC (Determination of thiocyanate in serum by HPLC). In Qualität und Hygiene von Lebensmitteln in Produktion und Verarbeitung. Proceedings of the 105th Kongress des Verband der Landwirtschaftlichen Untersuchungs- und Forschungsanstalten (VDLUFA), pp. 677-679 [H. Zarges, editor]. Darmstadt, Germany: VDLUFA Verlag.

Rundgren, M. (1983). Low-glucosinolate rapeseed products for pigs - a review. Animal Feed Science and Technology 9, 239-262.

Sandell, E. B. \& Kolthoff, I. M. (1937). Microdetermination of iodine by a catalytic method. Mikrochimica Acta $1,9$.

Schöne, F., Hennig, A., Groppel, B. \& Lange, R. (1991a). Evaluation of low or high glucosinolate rapeseed meals in experiments with growing pigs and poultry. In Rapeseed in a Changing World. Proceedings of the 8th International Rapeseed Congress, pp. 382-389 [D. I. McGregor, editor]. Saskatoon, Canada: University of Saskatchewan.

Schöne, F., Jahreis, G., Kirchheim, U. \& Deschner, F. (1994a). Wirkung von Glucosinolaten und Jod auf die Schilddrüse und die Serum $\mathrm{T}_{4}$-Konzentration rapsgefütterter Schweine (Effect of glucosinolates and iodine on 
thyroid and serum $\mathrm{T}_{4}$ concentration of rapeseed fed pigs). Proceedings of the Society for Nutrition Physiology 2, 53 Abstr.

Schöne, F., Jahreis, G., Lange, R., Seffner, W., Groppel, B., Hennig, A. \& Lüdke, H. (1990). Effect of varying glucosinolate and iodine intake via rapeseed meal diets on serum thyroid hormone level and total iodine in the thyroid in growing pigs. Endocrinologia Experimentalis 24, 415-427.

Schöne, F., Kirchheim, U. \& Schumann, W. (1994b). Glucosinolate degradation by rapeseed myrosinase and effect on rapeseed acceptability by growing pigs. Animal Feed Science and Technology 48, 229-235.

Schöne, F., Kirchheim, U. \& Schumann, W. (1995). Full fat rapeseed and rapeseed press cake in pig feeding. In Proceedings of the Ninth International Rapeseed Congress, Cambridge, pp. 151-153. Dorchester: The Dorset Press.

Schöne, F., Lüdke, H., Geinitz, D. \& Grün, M. (1991b). Effect of low or high glucosinolate rapeseed meal on growth, thyroid hormone, vitamin A and trace element status of pigs. In Rapeseed in a Changing World. Proceedings of the 8th International Rapeseed Congress, pp. 1577-1584 [D. I. McGregor, editor]. Saskatoon, Canada: University of Saskatchewan.

Schöne, F. \& Paetzelt, H. (1987). Feeding of high glucosinolate rapeseed meal or administration of potassium thiocyanate and excretion of $\mathrm{SCN}^{-}$in the urine of growing pigs. In Proceedings of the 7th International Rapeseed Congress, vol. 7, pp. 1735-1741 [J. Krzymanski, editor]. Poznan, Poland: Plant Breeding and Acclimatization Institute.

Spiegel, C., Bestetti, G., Rossi, G. \& Blum, J. W. (1993). Feeding of presscake meal to pigs: effects on thyroid morphology and function and on thyroid hormone blood levels, on liver and on growth performance. Journal of Veterinary Medicine, Series A 40, 45-57.

Steel, G. G. \& Torrie, J. H. (1980). Principles and Procedures of Statistics. 2nd ed., pp. 186-187. New York and Toronto: McGraw-Hill Inc.

Taurog, A. (1985). Hormone synthesis: thyroid iodine metabolism. In Werner's The Thyroid, 5th ed., pp. 53-97 [S. H. Ingbar and L. E. Braverman, editors]. Philadelphia: J. B. Lippincott Company.

Tiran, B., Wawschinek, O., Eber, O., Beham, A., Lax, S. \& Dermelj, M. (1991). Simple determination of iodine in small specimens of thyroid tissue. Experimental and Clinical Endocrinology 98, 32-36. 